Etnográfica

Revista do Centro em Rede de Investigação em

Antropologia

vol. $22(3) \mid 2018$

Vol. 22 (3)

\title{
When homebirth "goes wrong": holistic mothers who end up giving birth in a Portuguese hospital
}

Quando um parto em casa "corre mal": mães holísticas que acabam por dar à luz num hospital português

\section{Anna Fedele}

\section{(2) OpenEdition}

\section{Journals}

Electronic version

URL: https://journals.openedition.org/etnografica/6099

DOI: 10.4000/etnografica.6099

ISSN: 2182-2891

\section{Publisher}

Centro em Rede de Investigação em Antropologia

\section{Printed version}

Date of publication: 1 October 2018

Number of pages: 691-714

ISSN: 0873-6561

\section{Electronic reference}

Anna Fedele, "When homebirth "goes wrong": holistic mothers who end up giving birth in a Portuguese hospital", Etnográfica [Online], vol. 22 (3) | 2018, Online since 10 October 2018, connection on 20 January 2022. URL: http://journals.openedition.org/etnografica/6099 ; DOI: https://doi.org/10.4000/ etnografica.6099

\section{(c) (i) (8)}

Etnográfica is licensed under a Creative Commons Attribution-NonCommercial 4.0 International License. 


\section{When homebirth "goes wrong": holistic mothers who end up giving birth in a Portuguese hospital}

\section{Anna Fedele}

The article is based on research about holistic mothering in contemporary Portugal. Holistic mothering is an umbrella term, used here to describe different mothering choices based on the assumption that pregnancy, birthing and early mothering are important spiritual experiences for the mother and the child, but also for the father. In Portugal, many holistic mothers choose homebirth and avoid what they perceive as excessive medicalization during hospital birth. Influenced by Davis-Floyd's analysis of birth as an American rite of passage and her distinction between a technocratic and a wholistic model of birth, Portuguese holistic mothers conceptualize homebirth as a rebellious choice that subverts the predominant, biomedical model. The subversive aspects of homebirth are underscored by the fact that it exists in a legal void and is presented in the media and in popular discourse as a dangerous choice that poses an obstacle to the country's modernization. Drawing on ethnographic data, I argue that the entrenchment of two opposing models, what Davis-Floyd calls the wholistic and the technocratic, is counter-productive and contributes to traumatic experiences for holistic mothers who choose homebirth but who end up hospitalized, and consequently targeted for critique by the medical establishment and the wider social environment, which originates a sense of guilt and/or inadequacy for not being able to follow-through with the birth at home.

KEYWORDS: homebirth, holistic mothering, wholistic model, technocratic model, hospital birth, Portugal.

Quando um parto em casa "corre mal": mães holísticas que acabam por dar à luz num hospital português - $\mathrm{O}$ artigo resulta de uma investigação sobre a maternidade holística no Portugal contemporâneo. A expressão "maternidade holística" descreve, de forma genérica, as escolhas de maternidade que pressupõem que a gravidez, o nascimento e a maternidade são experiências espirituais importantes para a mãe e para a criança, mas também para o pai. Em Portugal, muitas mães holísticas escolhem o parto domiciliar para evitar o que entendem ser uma excessiva medicalização durante o parto hospitalar. Influenciadas pela análise de Davis-Floyd sobre o nascimento como um rito de passagem americano, e pela sua distinção entre um modelo tecnocrático e um modelo holístico, essas mães conceptualizam o parto domiciliar como uma subversão do modelo biomédico predominante. Os aspetos subversivos desta escolha são enfatizados pelo facto de este tipo de parto não ser legalmente reconhecido e ser considerado pelos meios de comunicação e pela opinião pública como uma escolha perigosa que representa um obstáculo ao processo de modernização do país. Usando dados etnográficos, argumento que a construção de dois modelos opostos, o tecnocrático e o holístico, pode resultar em experiências traumáticas para as mulheres que escolhem um parto 


\begin{abstract}
domiciliar mas acabam por dar à luz num hospital. Criticadas pelo pessoal médico, pelos meios de comunicação e pelo ambiente social, estas mães holísticas vivem sentimentos de culpa e/ou sentem-se inadequadas porque não foram capazes de dar à luz em casa.

PALAVRAS-CHAVE: parto domiciliar, maternidade holística, modelo tecnocrático, modelo holístico, parto hospitalar, Portugal.
\end{abstract}

FEDELE, Anna (fedele.anna@gmail.com) - Centro em Rede de Investigação em Antropologia, ISCTE - Instituto Universitário de Lisboa (CRIA-IUL), Portugal.

\begin{abstract}
"Giving birth was for me a unique event of empowerment, something that convinced me that I am capable of accomplishing everything, that I am wonderful because I am a woman. [...] Giving birth truly transformed me, that rite of passage made me into a person that trusts herself more, is more at peace with the world and happier."
\end{abstract}

THIS IS HOW A PORTUGUESE WOMAN IN HER EARLY 30S WITH A BA in anthropology described her experience of birthing her first child at home. Her words, shared during the seminar that gave rise to this dossier (see Fedele and White, this volume), exemplify the worldview of holistic mothers (Fedele 2016) in Portugal and, in particular, their conceptualization of birth as an important rite of passage for women. I use "holistic mothering" as an umbrella term to describe different mothering choices that are rooted in the assumption that pregnancy, childbirth and early childhood are of crucial importance to the child's development as well as to the wellbeing of the mother, and that there is a spiritual dimension to both pregnancy and mothering. In this context, birth is considered one of the most important events in a person's life, with psychological as well as spiritual consequences for the mother and the child, but also for the father or other persons assisting at the birth and acting later as secondary caretakers for the baby.

Drawing on primary ethnographic data, I analyse how holistic mothers, influenced by humanization of birth movements but also by holistic spiritualities, seek to have a birth experience that is radically different from what is commonly available in hospital, which is predominantly founded on a biomedical model. ${ }^{1}$ These mothers see the biomedical model of birth as perpetuating a 
series of interventions and procedures that are disempowering for women and that serve to establish not only the superiority of technology over nature, but the ultimate authority of the medical establishment. In Portugal there are, of course, women who refuse the biomedical model of birth without embracing theories and practices related to holistic spiritualities or holistic mothering, but for my research, I chose to focus on women whose rejection of the Portuguese biomedical model was embedded in their holistic worldview (see below for a detailed description of holistic mothering) and in their conceptualization of birth as an important rite of passage (see also Grimes 2000).

In the case of Portugal, homebirth appears as a particularly subversive act because, as we will see in more detail below, it tends to be represented by the media and couched within Portuguese public opinion as a radical, rebellious choice that represents a threat not only to mother and baby, but also to the modernization process of the country (Fedele and Pasche Guignard 2018).

Influenced by Robbie Davis-Floyd's (2003 [1992]) analysis of birth as an American rite of passage, holistic mothers perceive the biomedical approach to birth used in Portuguese hospitals as an expression of a "technocratic" model of birth that is disempowering for women because both pregnancy and birth are conceived within a patriarchal framework. My informants advocate a model of birth based on a female perspective that trusts a woman's natural capacity to give birth and that considers the mother and the baby intimately interrelated. In Portugal, one of the European countries with the highest medicalization and caesarean rates (see Fedele and White, introduction to this dossier), homebirth often appears as the only possible choice for holistic mothers who want a birth with as little medical intervention as possible. ${ }^{2}$

In the first part of the article I briefly present Davis-Floyd's (2003 [1992]) two models of birth and their influence on holistic mothers in Portugal. After describing my informants' worldview and the methods that guided my research, I situate them in the wider context of birth and homebirth in Portugal. Two case studies of women who had planned and attempted homebirth but whose actual birth experiences took them to hospital allow us to understand how holistic mothers negotiate and adapt symbolic meanings as well as their bodily experiences after an incomplete, or failed, homebirth. In Alda's case, she gave birth to her child at home but was forced to go to hospital for the final phase of birth, the delivery of the placenta. The comparison between how she was treated and how she felt at home versus her experience of the

later as an FCT investigator (IF/01063/2014). I am grateful to Joanna White, Ema Hrešanová, Mário Santos, Elizabeth Challinor, Ramon Escuriet, Francesca De Luca and Florence Pasche Guignard who provided important suggestions. Susan Scott took care of the editing and provided useful comments. 2 There are also Portuguese women who seek homebirth because of their antipathy towards medical intervention and who do not embrace holistic mothering. 
hospital exemplifies well the contrasts between these two settings and the clash in worldviews they signify. Carla's story reveals the sense of failure a holistic mother experienced having to give birth in a hospital, and the way in which this particular mother felt excluded from the community of homebirthing mothers.

Drawing on these case studies, I argue that the conceptualization of birth in terms of two oppositional models can have negative effects on women who cannot have the homebirth they had originally sought. The traumatic experiences described by my informants are related not only to the negative response of health professionals in the hospital but also to a sense of guilt and inadequacy the mothers then suffer. And, while similar problems may exist to varying degrees elsewhere, this collision of birth-views is especially evident in Portugal, where homebirth still exists in a legal void and where homebirthers are widely criticized on all fronts, both by the medical establishment and by public opinion.

\section{THE TECHNOCRATIC AND THE WHOLISTIC MODEL}

In her influential book Birth as an American Rite of Passage, an ethnography of hospitalized birth in the US, anthropologist Davis-Floyd (2003 [1992]) argues that "although there appears to be no society-wide spiritual rite of passage to initiate newborn mother and child into American life," one can observe "a surprising standardization of medical procedures for childbirth across the country" that is "most reminiscent of the standardized rituals that make up rites of passage in traditional societies" (2003 [1992]: 1). Davis-Floyd's insightful critique of what she calls the technocratic model of birth in American hospitals describes it as a ritualized attempt to transmit values and practices that reaffirm the supremacy of technology and of the male. She then describes a wholistic model that challenges technocratic assumptions, by considering pregnancy and birth from a female perspective. More than 25 years have passed since the publication of what has now become a medical anthropology classic as well as a renowned work in the field of ritual studies and gender studies. What is important for the purposes of this text, however, is that her work has also become an important direct or indirect source for women in Europe, the US, Canada and Australia who are part of international social movements that want to promote the humanization of childbirth.

My Portuguese informants used the term holístico, translated by me as "holistic," to describe their worldview and birthing choices. The distinction between "wholistic" and "holistic" in English does not exist in Portuguese. In this text I use "wholistic" when referring to the kind of model proposed by Davis-Floyd (2003 [1992]) that influenced my informants. At the same time, I refer to the women I met during fieldwork as "holistic" mothers to remain consistent with 
other works I have published on this topic (Fedele 2016; Fedele and Pasche Guignard 2018).

According to Davis-Floyd's (2003 [1992]) description, those embracing the wholistic model consider the pregnant mother and her unborn child as an "inseparable and independent whole," and take the family as the "significant social unit." The human body is perceived as "a living organism with its own innate wisdom, an energy field constantly responding to all other energy fields." In this context, health or illness appear as "the manifestation of the health or illness of one's self, one's daily life, one's family, one's past, one's society - one's whole world" (Davis-Floyd 2003 [1992]: 155-156). According to this model, then, the needs of mother and baby are complementary. Both "choose each other and form one energy field" so that, for instance, the mother's need for a homebirth, which she perceives as self-empowering, will not present a problem for the safety of the child (2003 [1992]: 157). The mother "knows" how to give birth to her baby and the doulas, ${ }^{3}$ midwives, doctors, technicians and so on should be there to serve the mother and not to control her or impose certain choices upon her.

To compare the technocratic model and the wholistic model, Davis-Floyd (2003 [1992]: 160-161) presents them as a table, with two contrasting sets of attributes. Note that wholistic attributes tend to reverse technocratic attributes. I quote in table $\mathrm{I}$ some of the attributes that are most relevant for the topics addressed in this article.

\section{Table 1}

The technocratic vs. the wholistic model of birth

The technocratic model of birth

Male perspective

Woman $=$ object

Female $=$ defective male

Pregnancy and birth inherently pathological

Fetus is separate from mother

Supremacy of technology

Once labor begins, it should progress steadily; if it doesn't, intervention is necessary

Responsibility is the doctor's

The doctor delivers the baby
The wholistic model of birth Female perspective Woman $=$ subject

Female normal in own terms

Pregnancy and birth inherently healthy Baby and mother are one Sufficiency of nature Labor can stop and start, follow its own rhythms of speeding up and slowing down

Responsibility is the mother's

The mother births the baby

Source: Davis-Floyd (2003 [1992]: 160-161)

3 A doula is a person without medical specialization who assists a woman and her close family before, during and after childbirth. 
Holistic mothers aim to affirm the values of the wholistic model, introducing both the newborn baby and mother into a social group that shares the theories and practices related to holistic mothering and holistic spiritualities more generally.

In her article "Reinscribing the birthing body: homebirth as ritual performance," anthropologist and midwife Melissa Cheyney analyses homebirths in America as "transgressive rites of passage," [...] "intentionally manipulated rituals of technocratic subversion designed to reinscribe pregnant bodies and to reterritorialize childbirth spaces (home) and authorities (midwives and mothers)" (2011: 519). Cheyney uses Davis-Floyd's critique of the technocratic model as reinforcing patriarchal and biomedical values already predominating in American society as a "comparative model" to examine the ways in which American midwives assisting at homebirths challenge hospitalized practices. Like Cheyney, I also found that holistic mothers, as well as the doulas, friends and midwives who accompany the mothers during pregnancy, birth and motherhood, adopt a wholistic model, in both theories and practices, with the aim of subverting the predominant (technocratic) model they perceive as patriarchal and therefore disempowering for women.

Cheyney observes that what remains unclear from her research "is what happens to ritual participants when plans for a home delivery go awry because of complications that require medical intervention" and "how the symbolic content of homebirth care is negotiated, adapted, and internalized when pregnancies or deliveries do not go as planned" (2011: 537) This article offers some early answers to Cheyney's questions and provides as well an analysis of the influence of religion and spirituality. More research on these topics is required, and as my own findings reveal, there is significant potential for future research to pay close attention also to the religious dimension of homebirth as well as to issues of gender and power within contemporary movements for the humanization of birth. I suggest that the use of qualitative methods, ethnographic research and life stories is particularly important to grasp the subtle ways in which dichotomized approaches to birth are sometimes intertwined with religious discourses and can have traumatic outcomes when plans for homebirth go wrong.

I should stress that my informants never used the term "technocratic." They used adjectives such as "biomedical," "patriarchal" or "dominant" to describe the kind of birth model they were criticizing and opposing. However, these women knew Davis-Floyd's analysis, either directly or through international, Portuguese or Brazilian texts or documentaries, and their conceptualization of the model they were opposing was very similar to that first described by Davis-Floyd. ${ }^{4}$ 
The main figures endorsing the wholistic model, such as the American spiritual midwifery practitioner Ina May Gaskin (2002 [1975]), for instance, are important sources for holistic mothers. Davis-Floyd's text, as well as other, later books that have been influenced by it (e.g. Goer 1995, 1999) are key reference works for doulas, midwifes and for the pregnant women embracing holistic mothering. ${ }^{5}$ Some of these texts have, in turn, been influenced by movements described under the umbrella term "holistic spiritualities" (also called New Age or contemporary spirituality).

Some scholars have already observed the influence of holistic spiritualities on alternative birth and mothering movements. Pamela Klassen (2001), for instance, described the influence of religion and particularly of contemporary forms of spirituality on women choosing homebirth in America and Canada. Florence Pasche Guignard has described the influence of holistic spiritualities on movements promoting homebirth as well as long-term breastfeeding and attachment parenting in francophone countries (Pasche Guignard 2015).

As Klassen has already pointed out, Davis-Floyd did not pay special attention to the spiritual dimension of the wholistic model (Klassen 2001: 23). Nor does Cheyney address the religious/spiritual background of the midwives and homebirthers she describes, or the influence of religion, especially holistic spiritualities, on the practitioners' theories and practices. However, in the case of holistic mothers in Portugal, their spiritual worldview plays an important role in their approaches to pregnancy and birth. Clearly, further research on the entanglements between alternative birthing, mothering choices and holistic spiritualities is needed.

\section{HOLISTIC MOTHERING}

For my research on the intersections between holistic spiritualities and alternative mothering and birthing choices, I carried out interviews and conducted participant observation in the greater Lisbon area (2013-2015). I attended not only public events related to homebirth and prolonged breastfeeding, but also conferences about alternative medicine and organic alimentation as well as meetings about Waldorf schooling and anthroposophical medicine that attracted many mothers and pregnant women. ${ }^{6}$ I interviewed Portuguese mothers of different ages who lived primarily in the greater Lisbon area but who came from different areas of Portugal. I should add that my daughter having being born in 2011 greatly helped me during fieldwork because my informants

5 See, for instance, < https://www.doulasdeportugal.org/blank > (last access in October 2018).

6 Anthroposophical medicine is directly related to anthroposophy, a spiritual philosophy created by Rudolf Steiner (1861-1925). Treatments include the use of anthroposophical remedies, counseling, massage and exercise (Zander 2008, 2011). See Fedele (2016) for more details about holistic mothers and anthroposophical medicine. 
felt I could better understand their experiences, having given birth for the first time only a few years earlier. I was able to carry out semi-structured interviews and to compile life stories with 11 mothers and two midwives and to have informal conversations with more than 50 holistic mothers. ${ }^{7}$ I have stayed in touch with the women I formally interviewed and have also made informal follow-up interviews with five of them. The mothers I interviewed are white, and most have been to university (BA level). They have a variety of jobs (some of them part-time), and most of my informants could be considered as part of a Portuguese lower middle class. Three of these mothers had undergone training to become doulas but only one was practicing on a regular basis.

Eight women I interviewed had planned to give birth at home; five of these had very positive experiences of homebirth and one had a last minute "free birth" (without assistance from the midwife or doula). The remaining two cases, those of Carla and Alda, are particularly relevant to this article, and their experiences are discussed in more detail below.

Reference to a "holistic worldview" was, I found, particularly useful for understanding the kind of spirituality embraced by my informants (Sointu and Woodhead 2008; Heelas and Woodhead 2005). These mothers emphasized the importance of developing a more holistic approach to pregnancy, birth and childcare, one that takes into account the individuality of mother and child but that also considers them intimately connected. References to this holistic approach emerged, for instance, when discussing with mothers the importance their parenting choices had in ecological terms, or the influence that negative family patterns could have during pregnancy and birth. Most of my informants did not describe themselves as holistic mothers though, and preferred in general to avoid labels; however, when I told them about the umbrella term I had chosen to describe them, they said they found it fitting (see also Fedele 2016).

Holistic mothers assert that birthing and breastfeeding are not only physiological processes but also spiritual occasions, and so choose what they regard as empowering ways of mothering, from homebirth, waterbirth and prolonged breastfeeding, to other forms of intensive parenting. ${ }^{8}$ The mothers I encountered refused to identify with specific movements such as La Leche League

7 Interviews were recorded and all interviewees signed release statements. The translations from Portuguese to English are mine. Taking into account the fact that Portugal is a relatively small country and that the number of independent midwives, doulas and Waldorf teachers is relatively restricted, some elements such as the exact localization of certain places or the nationality of certain people are kept intentionally vague to protect both the informant as well as the people involved in her life story. 8 Intensive parenting or attachment parenting is an international movement that originated in the UK and the US and endorses the proximity between parent and child. It involves activities such as baby wearing, co-sleeping and long-term breastfeeding (usually for three to four years but sometimes longer). See Hays (1996), Bobel (2002), Faircloth (2013) for case studies in the UK and the US. 
(Bobel 2002; Faircloth 2013), natural mothering (Bobel 2002) or intensive mothering (Hays 1996); rather, they had a pragmatic attitude, selecting those aspects of each movement that worked best for them, leaning towards a critique of parents who adhered to a strict set of ideas and rules. As we will notice below, my respondents are used to questioning theories and practices and prefer to create their own "bricolage" theories according to what works best for them, rather than embracing a pre-defined set of theories or joining a specific social and/or religious movement. They tend to work from the shared assumption that every baby and every mother are unique and that for this reason it makes no sense to establish rigid rules: every mothering experience will necessarily be different. For this reason, I prefer then to describe holistic mothering as a polythetic class (one that is characterized by a bundle of attributes, all of which are not necessarily possessed by each member of the class), with 12 attributes (Fedele 2016):

1. Holistic worldview

2. Importance of conscious pregnancy

3. Importance of "natural" childbirth

4. Importance of prolonged breastfeeding (more than six months)

5. Criticism of biomedical models of the body and request for a more woman-centred care

6. Importance of close contact between mother and child

7. Importance of close involvement of the father (or of another person, or persons who closely accompany the biological mother during pregnancy, birth and early motherhood, e.g. same-sex or heterosexual partners, friends, etc.)

8. Creation of rituals to celebrate pregnancy, birth and early childhood stages

9. Use of an energy discourse (Fedele 2018) ${ }^{9}$

10. Use of gender as a central element for religious and social criticism (Eller 1993: 6)

11. Emphasis on self-realization and self-authenticity (Heelas and Woodhead 2005: 78-90)

12. Sacralization of body and sexuality

9 According to the energy discourse, widely used within holistic spiritualities, everything is made of energy - an all-pervading divine life force that manifests itself through the material world. People need to become aware of this energy and learn how to take care of their "energy body" or the "aura" that envelopes their physical body. There exist different energy techniques to receive "light" or "positive" nurturing energy from the surrounding world, and to release the "heavy" or "negative" harmful energy. 
For reasons of brevity I will focus here only on those attributes that are more or less directly related to pregnancy and birth. ${ }^{10}$

All my respondents emphasized the importance of being conscious of what was happening inside their body during pregnancy and birth. They would listen to the corporeal changes, taking as much time as possible to tune into these experiences and to connect with the baby. Some of them described their difficulties facing memories and emotions that emerged during pregnancy and childbirth. These women tried to address potentially problematic issues through consciousness work and spiritual healing so they would not end up being a burden for themselves or the baby during pregnancy or birth.

The holistic mothers I interviewed also emphasized space as well as attuned embodiment, in other words, the importance of giving birth in a place where they felt safe and respected, with as little intrusion from doctors or other birth assistants as possible. For most women, this place was their home. That said, some of them explained that they had almost been forced to choose homebirth. Had the kind of care provided in Portuguese hospitals been different (i.e. allowing women to give birth in the position they wanted, in water, as well as the freedom to decline infant vaccination at birth, etc.), these women might have considered hospital birth a viable, reasonable option.

Although, by rejecting hospital birth, holistic mothers refused to give away their power to doctors who did not recognize the natural authority of women during the birthing process, similar to Pamela Klassen's (2001) homebirthers in North America, they nonetheless carefully selected those biomedical theories and practices that gave them a feeling of safety and comfort (Fedele 2016). My informants also used some biomedical terms to describe their experiences of birth, and sometimes ventured comparisons with what might have happened had they chosen to give birth in a hospital (Chasteen Miller 2009).

Many mothers honoured the birth through rituals that marked this important life passage. These included: burying the placenta, consumption, or creation, of a remedy made from placental cells; conservation of the umbilical cord; baby blessing.

During the seminar that marked the subsequent origin of this dossier, where I presented the 12 attributes of the polythetic class I use to describe holistic mothers in Portugal, the woman whose comments about homebirth open this article said: "Thank you, I just discovered that I am a holistic mother, while you were presenting the attributes I used it as a sort of checklist and ended up checking them all!" During a later interview, this first-time mother described her experience of homebirth as an empowering rite of passage. Her words,

10 For further explanations about the characteristics of a polythetic class and a full description of the 12 chosen attributes, see Fedele (2016). 
which I quote at the start of this article, reflect the attitudes of other mothers I interviewed that address three elements crucial to understanding holistic mothers and their choice of homebirth: the desire to experience birth as an empowering event in which the mother is in charge; the celebration of women's power to procreate; the conceptualization of birth as a rite of passage that is of utter importance for both mother and child, not only in terms of their physical and psychological well-being but also with respect to their spiritual development.

The following section allows us to better understand the challenge posed by these elements when holistic mothers are confronted with a local scenario that effectively devalues their preferences. Now we will see how and why, in Portugal, in some circumstances, something as intimate as birthing and mothering can stand out as particularly rebellious and contested acts.

\section{CHOOSING HOMEBIRTH IN PORTUGAL}

The articles presented in this dossier underscore just how high Portugal's rates of medicalization and caesareans are by European standards. Complementary and alternative health care practices (CAM) are only gradually being recognized and accepted by local authorities (Fedele 2016). Hospitalized birth, be it in a public or private hospital, is still presented to pregnant women as their only viable choice. With the rare exceptions of certain maternity units in the state system, it is mostly private clinics that offer any alternatives, such as allowing women to choose the position for birthing more freely, or the opportunity to give birth in water. That said, these options are quite expensive by Portuguese standards, which in turn introduces yet another complication for pregnant women. At the same time, homebirth brings with it its own financial burden, and some women I met told me they had difficulties affording homebirth (Fedele 2016). In addition, homebirth exists in a legal void. Women choosing it can expect to face many challenges in terms of discrimination (Santos 2012; White and Schouten 2014).

As the articles in this dossier show, the kind of standardized hospital birth procedures described by Davis-Floyd in the US in the 1980s (e.g.: intravenous feeding, electronic monitoring, epidural, episiotomy) are routinely practiced in Portuguese hospitals, where the doctor represents the ultimate authority and midwives have little decision-making power. ${ }^{11}$ Furthermore, in Portugal, common practices include the Kristeller manoeuver ${ }^{12}$ or the toque - vaginal sweep

11 However, as we can see in Challinor's paper in this dossier, there are also situations in which the mother can negotiate, but this depends on how much she is informed and on the personal contacts and networks she has to draw upon.

12 Defined in the Segen's Medical Dictionary (2011) as "The extinct practice of pressing on the uterine fundus to facilitate a vaginal delivery, which is now recognised as a dangerous manoeuvre that [continues] 
to induce labour (see White and Queirós, this volume; White 2016) - routines considered outmoded, too intrusive and even potentially dangerous in other European settings (see Fedele and White, this volume).

In this complex environment, some holistic mothers choose homebirth not because they see the home as the ideal place to give birth but rather because, after evaluating different scenarios, they find that only homebirth allows them to maximise the possibility of both mother and child avoiding medical intervention (Fedele 2016). As I have argued elsewhere, drawing on Pamela Klassen's ethnographic analysis (2001) of homebirth and religion in North America, holistic approaches to mothering in Portugal represent an important means of challenging biomedical models of the body (Fedele 2016). These challenges should be considered in the wider context of pressuring for a more women-centered model of birth that has already led to important transformations in other European countries.

In Portugal, however, such transformations have yet to take root. Homebirthers are generally characterised within public opinion as irresponsible, "bad mothers" (Fedele 2016) and, indeed, there have been some widely broadcasted scandals related to homebirth. ${ }^{13}$ In these debates homebirth is described as a dangerous choice that puts the life of both baby and mother at risk. In comments and blog-posts, people criticized homebirth choices as threats to the modernization process of hospitals in Portugal and to governmental efforts to improve the public health system overall (Fedele and Pasche Guignard 2018). ${ }^{14}$ The homogeneity of cultural messaging here is striking: neither journalists nor the media outlets that framed these stories noted the fact that in other European countries, such as the Netherlands or the UK, a mother's choice to give birth at home is endorsed and regulated by the state; midwives collaborate closely with certain hospitals and clinics with institutional support; emergency transfer procedures are in place; and homebirth is considered safe, standard and uncontroversial.

The descriptions I heard of what happened when homebirth "went wrong" - and these from women who did not know each other - were quite similar, and the scenario they described was also confirmed by the two midwives I

[continuation] carries the risk of uterine rupture" (in $<$ https://medical-dictionary.thefreedictionary. com/Kristell er\%E2\%80\%99s + manoeuvre >, last access in October 2018). See also Fedele and White (introduction to this dossier).

13 A good example is the case of popular actress Adelaide Sousa's planned homebirth that ended as a caesarean and merited the cover page of Portugal's most popular celebrity magazine, Caras (in $<$ http:// caras.sapo.pt/assinaturas/2009-09-01-caras---edicao-734 > (last access in October 2018).

14 See for instance this post on the blog of TSF (published on April 1, 2012) where obstetricians are reported to equal homebirth with a "return to the Middle Ages": < http://www.tsf.pt/portugal/ saude/interior/obstetras-criticam-publicidade-de-enfermeiros-a-favor-de-partos-em-casa-2374968. html?id=2374968 > (last access in October 2018). 
interviewed. For instance, instead of gathering information from the midwives and doulas who had been following the birthing woman throughout pregnancy and part of the birthing process, the attending doctors simply sent these individuals away. ${ }^{15}$ Medical personnel often refused to take seriously the information offered by the birthing women themselves, and instead treated them as unreliable informants. In this context, given the poor dialogue and lack of collaboration between the medical establishment and those choosing alternative forms of birthing, homebirth becomes an even more potentially dangerous choice. Consequently, homebirths that end up in hospital are almost doomed to become traumatic experiences for the birthing mothers. ${ }^{16}$ Scholars conducting research in other European countries such as the Czech Republic (Hrešanová 2017), where the government does not approve of or endorse homebirth, have observed similar scenarios and found that when complications arise and homebirthers end up in hospital, they are received with criticism and hostility.

\section{"A LITTLE STUPID IRRESPONSIBLE PERSON WHO IS GOING TO PUT THE ENTIRE SOCIETY AT RISK"}

Alda's story reflects the traumatic experiences of other holistic mothers, and also of mothers I encountered whose planned homebirth was disrupted, resulting in their hospitalization, and who would not necessarily fall into the category of holistic mothers. Alda's story is particularly interesting in comparative terms, because the birth of her baby and the delivery of her placenta took place in different spaces and with radically different approaches to care.

Alda grew up in the south of Portugal and received a BA in education. In 2008 she started training as a Waldorf teacher, and this brought about a period of deep transformation. Her family was first shocked and considered her choice irresponsible, although they eventually went on to accept. Some months later Alda fell in love with Julio, who was also undertaking Waldorf training and had two sons from a previous marriage. Julio was living in a town north of Lisbon. Alda, however, kept working in a kindergarten in the south of Portugal until the last month of her pregnancy. She then moved north to live in Julio's

15 In some cases, the midwife and/or the doula refused to accompany the birthing woman to the hospital because of previous negative experiences or because they were afraid to be criticized or even persecuted.

16 It is certainly not my intention here to reinforce the idea that is already widespread in Portugal that homebirth is inherently dangerous. There is evidence - see for instance the recent birthplace cohort study in the UK, in < https://www.npeu.ox.ac.uk/birthplace/results > (last access in October 2018); as well as Abraham-Van der Mark (1996) - that homebirth can be a safe and empowering choice for both the mother and the child if it happens in an environment in which there is an agreement with the local health system and homebirth is recognized and encouraged as a valid choice by the government. Unfortunately, such recognition and collaboration do not exist in Portugal (see Fedele and White, introduction to this dossier). 
house and had planned to give birth there. During her pregnancy, she went to the regular check-ups at the health centre and was cared for by Elisabeth, a north-European midwife. A doula who lived close to Julio's town also assisted throughout the pregnancy.

Two days before her due date, while Alda was about to fall asleep, she felt warm liquid gently seeping out between her legs: her water had broken. Calm and full of strength, Alda called Julio and Elisabeth, who were both in the south of Portugal. The midwife advised her to go back to sleep and Julio made sure that the doula slept in the room next to Alda. At four in the morning Julio and Elisabeth arrived and soon went to sleep as well. The next morning, as the contractions became stronger, Alda entered the pool, where she had planned to give birth. In fact, she ended up giving birth to her son Vitor outside the water, on her knees, with Julio holding her tightly and serving as support.

Alda was very proud of how she gave birth to her son and experienced this whole process as an empowering event. She was full of excitement when she pointed out the place in her living room where she had given birth and it was clear that this was for her a sacred space. Then, slowly, her voice and expression changed as she moved on to tell me about the "third phase" of her birth, something she rarely spoke about.

After Vítor was born, Alda began losing a lot of blood. The doula informed her that unfortunately the placenta was not detaching properly and they would have to go to the nearby hospital. When Alda heard this, she became very sad, because she "already knew what to expect." In her own words:

"I was here [at home] so well protected and now I have to go to a place where I do not know anybody, where I know that people will in some way mistreat me, not physically but verbally... [...] there at the hospital they did their job but not in a very nice way [...] I was criticized a lot. [...] I arrived at the hospital with my child, with a hemorrhage [...] lying on a mat and the nurse was telling the people 'birth at home by choice'. And a lady, I do not know whether she was a nurse or a doctor, said [...] 'and so why did they not solve this problem at home?' and [the majority of those at the hospital] kept waving their heads in disapproval with an attitude of putting me down and of condemnation."

Alda described one female doctor as being particularly "harsh":

"She was extracting the placenta and it was hurting like hell, and while I was feeling her hand entering inside of me she kept saying: 'never do this again if you want to have other children, you could have died,' and [she mentioned that] this and that could have happened, she was always very negative." 
Alda then described the following days at the hospital as a "massacre":

"There were some nice and kind people who tried to help, the nurses were taking care of me, but the doctors were also putting a lot of pressure [on me] to immunize [the son]. ${ }^{17}$ One of the elder doctors, who decided that I could go home, commented: 'we work hard for many years to improve the health system so that the women can have better conditions and people like you make this kind of blunder!'”

The doctor's commentary is revealing, and shows the kind of backlash women such as Alda face in hospital settings. The comments also demonstrate how, in Portugal, the medical establishment's refusal to recognize homebirth as a viable option is deeply tied to the notion that it also undermines the modernization of the Portuguese health system (see De Luca, Challinor, and White and Queirós, this volume; Fedele and Pasche Guignard 2018).

Confrontations with the nurses also took place. In the days that followed, Alda refused to be taught how to bathe her baby. In Portuguese hospitals mothers are routinely taught how to bathe their babies, under the assumption that mothers should give their babies frequent baths. Many holistic mothers, however, believe that frequent bathing can harm the sensitive skin of the baby, eventually leading to the appearance of rashes or dermatitis. In my interviews, I heard a great deal about the adequate frequency for bathing a baby. Like Alda, some mothers chose to wait several weeks before giving a complete bath to their babies. She relates what happened when she tried to exercise that choice:

"We stayed there for three days and every day they wanted to bath [Vítor] and to teach how to give a bath. I told them: "listen, I really appreciate that you want to teach me but the reality is that I will not give a bath to my baby. My baby was just born and he will have a bath when I think he should.' [They replied:] 'ok, so you will not receive the teachings about how to give the bath, and how will you know how to bath the baby once you are at home?'. I answered: 'Excuse me, luckily I have a mother who bathed me as well as her other two children. Mothers are also there for this kind of

17 Portugal is one of the few European countries that immunizes newborn babies. In Portugal babies are routinely immunized at birth against tuberculosis and hepatitis B (European Center for Disease and Control, in <http://vaccine-schedule.ecdc.europa.eu/Pages/Scheduler.aspx $>$ (last access in October 2018). Although vaccinations are not obligatory in Portugal, in my experience few people know this; vaccination is presented to them as a standard procedure and not as a choice. An important number of women I interviewed chose not to immunize their children at all; several of them did not want their babies to be immunized at birth but immunized them during the early years, although not necessarily against all the diseases foreseen by the Portuguese immunization plan. 
things, in the past it was done like this, elder people taught younger people. And Julio as well has already been a parent and knows how to bath a baby. So, I thank you but you do not need to insist any more [...] for me it is too tiring to explain all this again and again every day to the same person."

Based on biomedical and widespread popular views of health and hygiene, the nurses asserted that bathing after birth is an essential part of caring for the baby and that mothers need to be taught how to do it properly, even if the mothers themselves feel they do not need to be instructed. Alda pointed out how the biomedical model does not recognise the natural ability of the mother to take care of her child and the authority of the family as the main social unit in charge of the child overall. In her words: "You feel like an intrusion, you feel that they are completely invading your space. There is no respect for your decisions because it is almost as if you were a little stupid irresponsible that is going to put the entire society at risk."

Alda sensed that her refusal to accept and follow the nurses' theories and practices related to bathing was perceived as a danger to "the entire society." During her account she also emphasized the important role played by Julio, without whom she felt she would not have been able to resist this kind of pressure to follow biomedical procedures. Julio was with her the whole time, maintaining close bodily contact with Vítor whenever Alda was unable to do so. Julio's confident attitude, his previous experience with childbirth and children, and the fact that he knew some of the nurses, were crucial elements that differentiated Alda's experience from that of other first-time holistic parents I met who did not feel confident enough to confront or resist the doctors and nurses. Julio's support as well as that of her wider Waldorf community allowed Alda to overcome these difficult events and to re-conceptualize her birthing experiences in a positive way.

Indeed, she also found a spiritual-psychological explanation for the partial failure of her homebirth. Alda's mother had the same problem with the detaching of the placenta when bearing her youngest child. Alda therefore interpreted her difficulty in expelling the placenta as hereditary, but she also explained this fact in holistic terms, drawing on what she had been told by the doula after the birth and on the strength of results of an aura reading some weeks before Vítor's birth. ${ }^{18}$ According to the reading, it was difficult for Alda to leave behind the kindergarten and all the children she loved and to move to Julio's house. Alda then interpreted her difficulty in expelling the placenta as being closely related to her difficulties to really feel at home in Julio's house

18 Within holistic spiritualities, "aura" is the name given to the energy field that surrounds each person. While the aura is usually invisible to human eyes, it can be seen and its frequency and/or colors "read" by those who claim to be able to see it or sense it. See also footnote 9. 
and her desire to be close to her family and to "her" kids. It is important to stress that this holistic interpretation was not in competition or in contradiction with the scientific explanation: both, to Alda, were useful.

Alda did regret not being able to celebrate the ritual with the placenta she had envisioned. In her own words, her placenta "was considered by the personnel in the hospital as waste" and therefore disposed of. Alda and Julio had planned to bury the placenta in their garden, under an almond tree, a choice that had mythological connotations and that would have helped Alda to feel some rootedness in the north of Portugal. Alda explained that the almond tree does not normally grow in the northern part of the country and is a typical tree of the south. According to legend, a princess of the north married a king from the south and moved to his domain. She missed her homeland, especially the snow, and so her loving husband ordered many almond trees planted, enough to create a shower of white petals when blooming, thereby making his wife feel as if it were snowing, and so feel more at home.

Alda did not create another ritual to compensate for this loss but she did hope, she said, that she would be able to give birth to her second child at home. In the future, then, because she would be better prepared, she would also be able to celebrate the placenta ritual.

\section{DEALING WITH FAILURE}

Alda's story is unequivocal: for as long as she remained at home, assisted by the doula, the midwife and her partner, she felt safe and well. However, feelings of safety and confidence faded dramatically when she arrived at the hospital, a place where her worldviews and birthing choices were not recognized and where she felt she was treated as an irresponsible, foolish person.

Although from Alda's perspective her plans had been completely disrupted, she managed to make sense of this failure by working with the explanations offered by the doula and the aura reader to reconfirm the validity of the wholistic model. As we have seen, according to this model, the mother and the baby (and also the placenta) are one, meaning that if the mother feels that homebirth is an empowering option, it will not be at odds with the safety or the wellbeing of herself or the baby. There is, however, an underside to this model, in that it also suggests that the mother can harbour fears unconsciously, or have attachments that she does not have control over, and these may create problems during the birth process. For that reason, Alda suspects that in some unconscious way it might have been her fault that the placenta did not detach properly. At least on a symbolic level, then, Alda, like the placenta, was unable to detach herself from her previous environment. The ritual that Alda and Julio wanted to celebrate, burying the placenta, further confirms the connection between the placenta's failed detachment and Alda's inability to 
detach from Southern Portugal at the end of her pregnancy. This was a ritual, as already described, designed to reinforce Alda's attachment to her new home while also celebrating her origins.

Interpreting problems that occur during pregnancy or birth as the consequences of conscious or unconscious fears and/or resistances of the mother (and sometimes even of the father) is common within the holistic worldview embraced by my informants. Also, the tendency to interpret obstacles or problems one encounters in spiritual-psychological terms has been observed by other social scientists studying holistic spiritualities (e.g. Luhrmann 1989; Knibbe 2013). Not surprisingly, this interpretive line of thinking can be problematic. It may provoke a sense of guilt in the mother who feels she did not work hard enough to solve her personal issues or was not committed enough to homebirth or a holistic worldview. As we have seen, Alda preferred not to tell other women about what she called "the third phase of her birth" that took place in hospital, because she did not want to scare them but also because she felt sad about what happened and did not generally want to divulge the story.

I met several holistic mothers who, unlike Alda, did not have the strength to insist on their birth plan and/or post-natal choices once they were in the hospital because they were exhausted and vulnerable and/or did not have a supportive partner or birth assistant who could advocate for the mother with resistant staff. Instead, these women ended up simply following the doctors' or nurses' suggestions or decisions, an experience that left them feeling disempowered but also profoundly guilty. Guilty because such women had not been able to fight to remain true to their initial birth plan.

Carla's case, which we will briefly explore here, illustrates this scenario particularly well.

Carla became pregnant several months after getting involved in holistic spiritualities and alternative mothering groups. Although she had planned a homebirth, she ended up giving birth in a hospital, ${ }^{19}$ she was on the receiving end of what she described as "all the interventions she had tried to avoid." After inducing the birth, for instance, the doctor performed what was for Carla one of the worst procedures: the Kristeller manoeuvre. The isolation she felt afterwards is clear from her account: "After he was born I felt ashamed when confronted with the other women who... formed part of the movement for the humanization of birth and had managed to have their babies at home. As if I were not as good as them, or as if I were not good enough."

Carla felt that she had failed because she had relented and gone to the hospital. Even though she managed to refuse an episiotomy, Carla still thought of herself as somebody who did not have the strength to oppose what she perceived

19 To protect her identity, I avoided including further details about why Carla ended up giving birth in a hospital. 
as invasive procedures that had been foisted on her by the doctors. She did not feel part of the "tribe" of holistic mothers either, because she had not given birth at home. At the same time, because she had been forced to pass through the technocratic model and had neither chosen nor embraced it, she could not identify with the group of "other" mothers in her social environment who had chosen a hospitalized birth. As a result, Carla felt deeply disempowered. Her isolation was aggravated by the perception of certain friends participating in what she described as the Portuguese movement for the humanization of birth who wondered if she had not been brave enough or had not done enough spiritual work on herself to be adequately prepared for a homebirth.

These women's birth accounts raise important questions about competition between systems and models, be they medical, psycho-social, or spiritual. I would argue that, even if it derived from quite different birth experiences, Alda's and Carla's individual sense of failure depended to a great extent on the strongly polarized division between a wholistic (good) model and a technocratic (bad) model that persists among holistic mothers and among certain proponents of the Portuguese movements for the humanization of birth. This polarization is particularly evident in the Portuguese case, in which the technocratic model clearly predominates in the culture at large, and the wholistic model is only slowly being recognized by the government. There is a great distance between the two models, and, at present, very little successful bridgework between the two. Clearly, more research needs to be done to assess to what extent this polarization is also present in other countries and what kind of negative consequences it can have for women whose birth plans are interrupted, and who end up being treated in what they feel are hostile or unsettling hospital conditions.

As it emerges from the Portuguese cases analysed in this dossier, both hospitalized birth and alternative forms of birthing deserve closer analysis. We need to go well beyond a polarized representation of technocratic/wholistic, and take into account the agency of mothers, family members and friends accompanying the women during birth, as well as midwives, doulas, doctors and nurses who may act as "guardian angels" (Challinor, this volume) and who provide "windows of care" (White and Queirós, this volume) in order to encourage a more nuanced scenario to emerge (see also Fedele and White, introduction to this dossier). In line with Cheyney's findings in the US, we can certainly say that homebirth in the context of holistic mothering in Portugal is an act of rebellion: holistic rites are aimed at subverting the patriarchal values of the technocratic model and its attendant rites of passage. Moreover, as we have seen, homebirth is perceived both by the medical establishment and by public opinion as subverting the established order and Portugal's progress towards becoming a modern European health system.

In this context, one party's failure can easily be interpreted as the other party's success. Homebirths that end up in hospital tend to be seen by proponents 
of the medical establishment not only as a failure of the wholistic model but as inherent proof of the superiority of the biomedical establishment as a whole. Alda explained that she usually did not tell people about the third phase of her birth because she felt her story could scare those who were interested in the possibility of birthing at home. Indeed, the partial failure of her homebirth, she thought, might confirm its riskiness and even demonstrate the superiority of the technocratic model. Through this same mechanism, endorsers of the wholistic model interpret women's traumatic experiences of birth in hospital as proofs of the failure of the technocratic model.

Social scientists have noted the tendency to borrow from anthropological texts (e.g. Jencson 1989; Bell 1997: 263-265; Fedele 2013), as well as the wish to subvert patriarchal models, and to construct rituals that turn patriarchal values upside down (Brown 1997; Fedele 2013, 2014; Fedele and Knibbe 2013), as characteristics of holistic spiritualities. Certainly, from what we see here, holistic mothers in Portugal, influenced by David-Floyd's description of birth as a rite of passage and her distinction between a technocratic and wholistic model, confirm these tendencies. In this context, then, homebirth becomes a subversive act that inverts and undermines the technocratic model. It is the homebirth that goes awry, however, that reveals the problems inherent to this dichotomous approach.

Women like Alda and Carla experienced their failure to (fully) give birth at home as a traumatic experience in personal terms, because of the negative approach of health professionals but also because they feel guilty for not having been able to follow through on their plans or to defend themselves and their baby from the intrusion of doctors. The trauma extends to these women's socialization as new mothers, in that it marked their forced initiation into the social group of mothers who were hospitalized for birth. If some, like Alda, manage to reassert their belonging to the wholistic group by emphasizing the first, successful part of their birthing process, it falls to mothers like Carla, who have to acknowledge their reluctant membership in the hospitalized birth group, to develop strategies to accept this fact and to move on from there. Carla explained that she tried to come to terms with a sense of failure by adopting other practices related to holistic mothering, such as co-sleeping or long-term breastfeeding on demand. Even this path comes at a cost to the well-being of the mother. Not until her second child was born at home did Carla finally feel more at ease and not so "obsessed" with following the rules related to breastfeeding or co-sleeping. ${ }^{20}$

20 This kind of strategies after a failed homebirth have been observed also by Florence Pasche Guignard in her research on natural parenting in Francophone contexts and it is thanks to her careful reading of this text that I could develop my analysis further. 


\section{CONCLUSION}

In a country such as Portugal where homebirth is not recognized as a legal option, holistic mothers experience homebirth as a choice that is both rebellious (against the biomedical model) and potentially liberating (for self and baby). Notably, it is the rebellious label that sticks, whether or not the homebirth actually unfolds as planned. This push-back against conventional medical models of birth and natal care is informed by Davis-Floyd's (2003 [1992]) analysis of hospitalized birth in the US as "an American rite of passage," and the model emerges as a direct or indirect source of inspiration and cultural critique that influences the ways in which holistic mothers conceptualize their homebirth: as subverting the dominant technocratic model that reproduces a patriarchal system which disempowers women. Through the case studies of Alda and Carla, we see the difficulties faced by women in Portugal who seek alternatives to what they regard as the restrictive biomedical model. Faced with a lack of support for their choices, and poor communication between the medical establishment and proponents of the alternative care sector, these women are forced into an untenable position, that of dangerous and endangered outsiders.

Given these forces, it is not surprising that Portuguese holistic mothers who end up transferred to a hospital find themselves facing traumatic experiences, not least because of the negative reactions of health professionals. Moreover, since these women consider birth as a crucial rite of passage, the failure of the wholistic model of birth can easily be interpreted as the victory of the other, technocratic model and may result in the mother's perceiving at least part of her experience as defeat. In this context, hospitalized birth can be seen as a sort of forced initiation into a technocratic model, the very model holistic mothers refute and have tried so hard to subvert.

Analysing what happens when homebirth "goes wrong" permits us to see precisely how homebirth in Portugal is conceptualized as a subversive act, not only by those embracing it but also by those in opposition. Although an increasing number of women and health professionals criticize the ways in which the technocratic model is imposed in Portugal, many proponents of the medical establishment still consider homebirth "a return to the Middle Ages" (see footnote 14) and a threat to the modernization of Portugal (see also Fedele and White, introduction to this dossier; Fedele and Pasche Guignard 2018).

Strategies for adapting to these conflicting scenarios vary. Some women, like Alda, manage to pick and choose among the biomedical procedures they consider to be necessary and to refuse others, thanks in great part to the help of their husbands or birth assistants and to the support of a like-minded community. Others, like Carla with her first child without a group of supporters 
who could help her push back, end up marginalized and feeling judged by both those endorsing the humanization of birth and those in favour of the technocratic model.

I want to be careful here to stress something else as well. Although hospital birth tends to be considered a potentially negative experience within the holistic sphere in Portugal, this is not always the case, at least according to a 2015 survey about birth experiences by the Portuguese Association for the Right of Women During Pregnancy and Birth (APDMGP 2015). It must also be stressed that in Portugal things are slowly changing (see also Fedele and White, introduction to this dossier). Midwives working in hospitals are gaining in status there (albeit with resistance from some doctors) and are now more attuned to alternative sensibilities. Doulas or other accompanying figures can now be present at birth in hospital, although it should be added that they can easily be sent away if the doctor states that there is danger.

While the ground-breaking work of Davis-Floyd has influenced a generation of advocates and activists for women-centred birthing practices, 25 years on, we are seeing the results of entrenched divides in attitudes, language, practice, and support (or lack of it) for a range of birthing choices. More research is needed on women's experiences of birth in Portugal, as well as on the growing influence of holistic health approaches to birth, to understand where best to go from here. On an international level, more research is needed on issues of gender and power within the movement for the humanization of birth, through long-term studies that use qualitative analysis, participant observation and the elaboration of life stories in order to grasp the complexities of these social phenomena, taking into account also their religious and spiritual dimension. ${ }^{21}$ We also need nuanced research on birthing trauma, including feelings of failure and exclusion following problems during homebirth, in particular on how these compare to feelings of failure, guilt and loss expressed by women wanting a "natural" birth but who face having a caesarean (e.g. Schneider 2013). I hope that future research will allow both scholars and a wide range of practitioners to better evaluate the impact of this dualistic, oppositional approach and to contribute to raising awareness about the need to develop a common legislation in Europe and elsewhere that recognizes and supports women's choice to birth at home. 


\section{REFERENCES}

ABRAHAM-VAN DER MARK, Eva (ed.), 1996, Successful Home Birth and Midwifery: The Dutch Model. Amsterdam, Het Spinhuis.

APDMGP - ASSOCIAÇÃO PORTUGUESA PELOS DIREITOS DA MULHER NA GRAVIDEZ E

NO PARTO, 2015, Experiências de Parto em Portugal: Inquérito às Mulheres sobre as Suas Experiências de Parto. Lisbon, APDMGP.

BELL, Catherine, 1997, Ritual: Perspectives and Dimensions. New York, Oxford University Press. BOBEL, Chris, 2002, The Paradox of Natural Mothering. Philadelphia, PA, Temple University Press.

BROWN, Michael F., 1997, The Channeling Zone: American Spirituality in an Anxious Age. Cambridge, MA, Harvard University Press.

CHASTEEN MILLER, Amy, 2009, “'Midwife to myself': birth narratives among women choosing unassisted homebirth”, Sociological Inquiry, 79 (1): 51-74.

CHEYNEY, Melissa, 2011, "Reinscribing the birthing body: homebirth as ritual performance", Medical Anthropology Quarterly, 25 (4): 519-542.

DAVIS-FlOYD, Robbie E., 2003 [1992], Birth as an American Rite of Passage. Berkeley, CA, University of California Press ( $2^{\text {nd }}$ edition).

DELAPORTE, Marianne, and Morag MARTIN (eds.), 2018, Sacred Inception: Reclaiming the Spirituality of Birth in the Modern World. New York, Lexington Books.

ELLER, Cynthia, 1993, Living in the Lap of the Goddess: The Feminist Spirituality Movement in America. Boston, Beacon Press.

FAIRCLOTH, Charlotte, 2013, Militant Lactivism? Attachment Parenting and Intensive Motherhood in the UK and France. New York, Berghahn Books.

FEDELE, Anna, 2013, Looking for Mary Magdalene: Alternative Pilgrimage and Ritual Creativity at Catholic Shrines in France. New York, Oxford University Press.

FEDELE, Anna, 2014, "Reversing Eve's curse: Mary Magdalene pilgrims and the creative ritualization of menstruation", Journal of Ritual Studies, 28 (2): 497-510.

FEDELE, Anna, 2016, “'Holistic mothers' or 'bad mothers'? Challenging biomedical models of the body in Portugal", Religion and Gender, 6 (1): 95-11 1.

FEDELE, Anna, 2018, "Translating Catholic pilgrimage sites into energy grammar: contested spiritual practices in Chartres and Vézelay", in Simon Coleman and John Eade (eds.), Pilgrimage and Political Economy: Translating the Sacred. Oxford and New York, Berghahn Books.

FEDELE, Anna, and Kim KNIBBE (eds.), 2013, Gender and Power in Contemporary Spirituality: Ethnographic Approaches. New York, Routledge.

FEDELE, Anna, and Florence PASCHE GUIGNARD, 2018, "Pushing from the margins: 'natural childbirth' in contemporary holistic spiritualities and natural parenting in France and Portugal", in Marianne Delaporte and Morag Martin (eds.), Sacred Inception: Reclaiming the Spirituality of Birth in the Modern World. New York, Demeter Press.

GASKIN, Ina May, 2002 [1975], Spiritual Midwifery. Summertown, TN, Book Publishing Company ( $4^{\text {th }}$ edition).

GOER, Henci, 1995, Obstetric Myths Versus Research Realities: A Guide to the Medical Literature.

Westport, CT, Praeger.

GOER, Henci, 1999, The Thinking Woman's Guide to a Better Birth. New York, Berkley Publishing Group. 
GRIMES, Ronald L., 2000, Deeply into the Bone: Re-Inventing Rites of Passage. Berkeley, University of California Press.

HAYS, Sharon, 1996, The Cultural Contradictions of Motherhood. New Haven and London, Yale University Press.

HEELAS, Paul, and Linda WOODHEAD, 2005, The Spiritual Revolution: Why Religion Is Giving Way to Spirituality. Oxford, Wiley-Blackwell.

HREŠANOVÁ, Ema, 2017, "The natural childbirth movement in the Czech Republic", in Katalin Fábián and Elbieta Bekiesza-Korolczuk (eds.), Rebellious Parents: Parental Movements in Central-Eastern Europe and Russia. Bloomington, Indiana University Press, 277 $-306$.

JENCSON, Linda, 1989, "Neopaganism and the Great Mother Goddess: anthropology as midwife to a new religion”, Anthropology Today, 5 (2): 2-4, DOI: 10.2307/3033137.

KLASSEN, Pamela E., 2001, Blessed Events: Religion and Home Birth in America. Princeton, Princeton University Press.

KNIBBE, Kim, 2013, "Obscuring the role of gender and power in contemporary spiritualities", in Anna Fedele and Kim Knibbe (eds.), Gender and Power in Contemporary Spirituality: Ethnographic Approaches. London and New York, Routledge.

LUHRMANN, Tanya, M, 1989, Persuasions of the Witch's Craft: Ritual Magic and Witchcraft in Present-Day England. Oxford, Basil Blackwell.

PASCHE GUIGNARD, Florence, 2015, “The in/visibility of mothering against the norm in Francophone contexts: private and public discourses in the mediation of 'natural parenting'", Canadian Journal of Communication, 40 (1): 105-124.

SANTOS, Mário J.D.S., 2012, Nascer em Casa: A Desinstitucionalização Reflexiva do Parto no Contexto Português. Lisbon, ISCTE - Instituto Universitário de Lisboa, master thesis.

SCHNEIDER, Dana A., 2013, "Helping women cope with feelings of failure in childbirth", International Journal of Childbirth Education, 28 (1): 46-50.

SOINTU, Eeva, and Linda WOODHEAD, 2008, "Spirituality, gender and expressive selfhood”, Journal for the Scientific Study of Religion, 47 (2): 259-276.

WHITE, Joanna, 2016, “'But isn't it the baby who decides when it will be born?': temporality and women's embodied experiences of giving birth”, Cambridge Journal of Anthropology, 34: 72-86.

WHITE, Joanna, and Maria Johanna SCHOUTEN (eds.), 2014, Normal Birth: Experiences from Portugal and Beyond/O Parto Normal: Experiências de Portugal e Além-Fronteiras. Braga, CICS, and Lisbon, CRIA.

ZANDER, Helmut, 2008, Anthroposophie in Deutschland: Theosophische Weltanschauung und Gesellschaftliche Praxis 1884-1945. Göttingen, Vandenhoeck \& Ruprecht.

ZANDER, Helmut, 201 1, Rudolf Steiner. München, Piper.

$\begin{array}{ll}\text { Receção da versão original / Original version } & 2016 / 07 / 18 \\ \text { Receção da versão revista / Revised version } & 2018 / 01 / 31 \\ \text { Aceitação / Accepted } & 2018 / 05 / 25\end{array}$

